Article

\title{
A Study of Strengthening the DNA Business as well as Priori- ties of Policies in the Case of South Korea
}

\author{
Yonghee Kim 1,", Jeongho Kwak 2,* \\ 1 College of Business Administration, Soongsil University, Seoul 06978, South Korea; yh.kim@soongsil.ac.kr \\ 2 Division of Big Data and Management Engineering Asan 31499, South Korea; jhkwak@hoseo.edu \\ * Correspondence: yh.kim@soongsil.ac.kr(Y.K.); jhkwak@hoseo.edu(J. K.)
}

Citation: Kim, Y.H.; Jeongho, Kwak. A Study of Strengthening the DNA Business as well as Priorities of Policies in the Case of South Korea. Sustainability 2021, 13, $\mathrm{x}$. https://doi.org/10.3390/xxxxx

\begin{abstract}
Recently, with the rapid advancement of the 4th Industrial Revolution, there has been a continuous outlook that Data (D), Network (N), and Artificial Intelligence (A) should be heavily utilized as resources in light of new value. South Korea is preparing policy training plans the likes of 5G network enhancement, AI manpower training, and data openings, etc., recognizing DNA technology as the key driving force behind the 4th Industrial Revolution and 5G network enhancement, AI manpower training, and data opening, etc. However, there is a criticism that the DNA industry remains in an early stage. Despite policy support within South Korea, the DNA industry has not been revitalized due to various causes, and in particular, not being concentrated on limited resources selectively is also pointed to as an important cause. this study would quantitatively draw the priority of policy measures as well as propose policy implications for the revitalization of the DNA industry by means of the ISM-ANP model. It is judged that South Korea's experience in this way will be an important lesson for other countries which would politically promote the DNA industry as a new growth engine within the 4th Industrial Revolution environment.
\end{abstract}

Keywords: Data, Network, Artificial Intelligence, Interpretive Structural Modeling, Decision-making; Brainstorming, Analytic Network Process

\section{Introduction}

The world economy is on the threshold of the 4th Industrial Revolution being converted quickly from the traditional economy centered on manufacturing for the Internet service-oriented digital economy. The digital economy creates new businesses or digital goods, crossing the boundaries between various industrial areas absent any constraints of time or space based on information and the Internet. Here, as the key elements of the digital economy giving rise to new businesses or digital goods, attention is drawn to Data (D), Network (N), and Artificial Intelligence (A). As a result, the digital economy has been evaluated as an alternative to new-innovation growth, referred to as the DNA industry since it pursues the convergence of various industries based on Data, Network, and AI as key technical bases.

Based on this background, major developed countries attach importance to the utilization of the technical elements including data, network, and AI as key resources alongside a new value for the enhancement of the era of the 4th Industrial Revolution. In fact, those countries which are judged to have successfully "logged in" to the digital economy from the so-called existing traditional economy jump to the center of the world economy, as DNA businesses lead the country's economic innovation, and the U.S. and China share the bulk of the world's top 10 businesses within the digital economy.

While major digitally developed countries prepare various policy measures such as R\&D investment and manpower training for the DNA revitalization, South Korea, too, promotes policy training plans, such as $5 \mathrm{G}$ network enhancement, AI manpower training, 
and data opening. This is in recognition of the DNA industry as the key driving force behind the 4th Industrial Revolution (The Presidential Committee on the 4th Industrial Revolution). Concretely, during 2020, South Korea's competent ministry for information and communication, the Ministry of Science and ICT (MSIT), compiled 16.2 trillion won as relevant budgets, an increase of 1.4 trillion won $(9.2 \%)$ in comparison to that of the previous year. The Ministry also compiled the R\&D budget scale, raising it to 7.9 trillion won, an increase of about 0.9 trillion won (13.6\%) in comparison to that during the previous year. As of 2020, the Ministry of Science and ICT (MSIT) budgets are going to be invested in economic growth through DNA enhancement, researcher-centered national R\&D system innovation, materials/parts/equipment industry competitiveness improvements, etc.

And yet, although South Korea has continuously promoted comprehensive policy measures for the revitalization of the DNA industry, criticism is raised that we remain in the early stage of the DNA industry. In this way, despite policy support, in South Korea the DNA industry has not been revitalized as compared to major DNA developed countries for various causes, and not having concentrated on limited resources selectively is pointed out as a very key cause.

Thus, this study would comprehensively examine various policy measures for the revitalization of the DNA industry through the lens of the 4th Industrial Revolution environment in rapid progress, draw the factors of policy measures for DNA revitalization utilizing ISM (Interpretive Structure Modeling) quantitatively draw the priority through ANP (Analytic Network Process) and propose related policy implications. It is expected that South Korea's experience through this way will provide an important clue for the countries which would promote the DNA industry as a new growth engine in terms of policies during the 4th Industrial Revolution environment.

The DNA industry refers to the convergence industry utilizing data (D), network (N), and AI as key technologies which come under the core technologies of the 4th Industrial Revolution. South Korea judges that it would be important to secure superior competitiveness in the DNA industry as compared to major developed countries for the sake of the success of the 4th Industrial Revolution and promotes multilateral policies for the strengthening of the core competencies for the DNA industry. The trends of policies for the revitalization of the DNA industry promoted by the Korean government untill now can be summarized within Table 1 below.

Table 1. Revitalization policies by major technologies of the DNA industry

\begin{tabular}{|c|c|}
\hline Classification & Details \\
\hline Data & $\begin{array}{l}\text { Strategies for promoting the data industry [1], Plan for the re- } \\
\text { vitalization of data/AI economy [2] }\end{array}$ \\
\hline Network & $\begin{array}{l}\text { Strategy for building up hyper-connected intelligent networks } \\
\text { to get ready for the } 4 \text { th Industrial Revolution [3], Early 5G fre- } \\
\text { quency allocation (June 2018), World's first commercialization, } \\
\text { nationwide coverage investment inducement [4] }\end{array}$ \\
\hline AI & $\begin{array}{l}\text { AI R\&D strategy [5] Plan for the revitalization of data/AI econ- } \\
\text { omy [2] }\end{array}$ \\
\hline
\end{tabular}

With the rapid advancement of the 4th Industrial Revolution in this way, various revitalization policies are promoted for the enhancement of Data, Network, and AI. First, revitalization policies for data technology and industry have been promoted twice, and promoting strategies for the data industry was announced as of June, 2018 [1], and a Plan for the revitalization of the data/AI economy during January of 2019 [2]. To look at them concretely, the Korean government established the data economy as the key strategy for innovation growth policies through the promotion of strategies for the data industry during June of 2018, fostering industries for the revitalization of the data economy such as the 
expansion of investments in the area of data and actively promoting the innovation of data utilization-related regulations such as the allowance of pseudonymous data. Then, during January of 2019, announcing the plan for the revitalization of the data/AI economy, it has promoted a policy execution plan which recognizes data and AI as a single integrated system. In other words, in the development of the DNA industry, data and AI have inseparable technical complementation.

Second, as revitalization policies for network technology and industry, policies for building up hyper-connected intelligent networks (Dec. 18, 2017) [3] and early 5G frequency allocation [4] were promoted. Here, measures for building up hyper-connected intelligent networks (Dec. 18, 2017) analyzed that the network infrastructure during the era of the 4th Industrial Revolution would serve as a kind of 'neural network' in which the data of all people and things are exchanged/communicated, and that as data and AI are converged based on the network, innovative convergence services would appear, such as autonomous vehicles, smart cities, smart manufacturing, and AR/VR. In particular, it judged that it would be important to enhance next-generation technologies including 5G, preceding other countries. Following that, policies for early 5G frequency allocation (June 2018) allocated 5G frequency to mobile carriers one year prior to what was outlined in the existing plan and put up $3.5 \mathrm{GHz}$ and $28 \mathrm{GHz}$ frequency bands at auction. South Korea succeeded in the commercialization of the 5G infrastructure on April 3, 2019, the first nation in the world to do so. Recently, it supports measures for expanding mobile carriers' investments by policies so that $5 \mathrm{G}$ infrastructure can secure coverage anywhere throughout the country.

Third, as for revitalization policies pertaining to the AI technology and industry, AI R\&D strategy was announced as of May 2018 [5], and a Plan for the revitalization of data/AI economy [2] as of January, 2019. Here, AI R\&D strategy (May 2018) seeks policy supports for securing world-class AI technologies and R\&D ecosystem and cultivating AI excellent talent, and Plan for the revitalization of data/AI economy (Jan. 2019) as the follow-up measures prepare a variety of policies for the establishment of the value chain to reach the collection, distribution, and utilization of data for the improvement of regulations for data economic revitalization as well as the promotion of the convergence between data and AI.

\subsection{ISM (Interpretive Structural Modeling)}

Interpretive Structural Modeling (ISM) was developed by the Vatel Columbus Laboratory in the U.S., which is a mathematical methodology that 1 ) investigates the problems of the project, using figures; or 2) determines the mutual relationship between factors, differentiating the functions by complicated factors [6,7]. ISM is able to determine the correlations among items constituting a problem complexly through the reachability matrix. Also, based on this, it is possible to identify the hierarchical structure of the items. Singh and Kant [8] described the 7 steps of ISM as follows.

- Step 1. This step includes identifying factors which are relevant to the study's research question. The elements can be done through reviewing literature or other collective problem-solving techniques.

- Step 2. This step includes constructing contextual relationships between factors in which a type of relationship between all other factors are to be assigned.

- Step 3. This step includes building up a structural self-interaction matrix (SSIM) of factors. This matrix emphasizes pair-wise relationships between factors inherent to the system identified during Step 2.

- Step 4. This step includes establishing a matrix of reachability based on the SSIM to verify the transitivity of each contextual relationship. Transitivity is utilized to form 
the fundamental assumptions in ISM which state the following: if Factor $\mathrm{E}$ is related to $F$ and Factor $F$ is related to $G$, then Factor $E$ will be related to $G$.

- Step 5. This step includes dividing the reachability matrix into different levels according to the outcome of Step 4.

- Step 6. This step includes drawing a directed graph, also called a digraph, according to the identified relationships stated in the matrix of reachability.

- Step 7. This step includes replacing notes between factors with statements in the digraph and converting the results of ISM.

Factors are determined during Step 1, and in Steps 2 and 3, Structural Self-Interaction Matrix (SSIM) is implemented. SSIM represents the relationships between the factors (i.e. $i$ and $j$ ) by earns of four symbols, including $\mathrm{V}, \mathrm{A}, \mathrm{X}$, and $\mathrm{O}$ [8].

- The relationship from $i$ to $j$ but not in both directions $=\mathrm{V}$

- The relationship from $i$ to $j$ but not in both directions $=\mathrm{A}$

- In both directions, the relationship from $i$ to $j=\mathrm{X}$

- There is no relationship between $i$ and $j=\mathrm{O}$

Step 4 reconstructs the reachability matrix from SSIM by utilizing the binary matrix for the calculations of driving power, dependence power, and iterations. The transitivity is also checked. The driving power is the sum of factors which are influenced by it plus itself. The dependence power is the sum of factors which possibly influence it plus itself [9]. Singh and Kant [8] explained this as follows by substituting V, A, X, and O with 1 or 0 used in SSIM [10].

- If $(i, j)$ is V in SSIM, then ( $i, j)=1$ and $(j, i)=0$ in the initial Reachability Metrix

- If $(i, j)$ is A in SSIM, then $(i, j)=0$ and $(j, i)=1$ in the initial Reachability Metrix

- If $(i, j)$ is $X$ in $\operatorname{SSIM}$, then $(i, j)=1$ and $(j, i)=1$ in the initial Reachability Metrix

- If $(i, j)$ is $O$ in SSIM, then $(i, j)=0$ and $(j, i)=0$ in the initial Reachability Metrix

Step 5 divides the reachability matrix into separate levels. To do so, the reachability matrix calculates the reachability set, antecedent set, and intersections of those sets pertinent to each factor. A reachability set is a factor itself and other factors which are influenced by it and the antecedent set function as a factor themselves, along with other factors which possibly influence it. The factors marked the same in the reachability set and intersections sets are found at the top level of the ISM hierarchy. This factor cannot affect other factors. If the elements at the top level are found, calculations are made repetitively until all factors are stratified, utilizing the reachability matrix from which this element has been removed.

Lastly, Step 6 draws a digraph based on the factor levels found in Step 5. First, to analyze the driving power and dependence power of each factor, each element is classified into four separate categories (Autonomous, Dependent, Linkage, and Driver) [11]. Next, according to the final reachability index as seen in Step 5, top-level factors are located at the top of the digraph, and second-level factors and so on are located below that. Also, the ISM-based Model is created, in which an arrow is shown according to the correlation of the pertinent factors.

\subsection{ANP(Analytic Network Process)}

ANP technique is a technique which was developed by Prof. Thomas Saaty during 1996. Prof. Saaty developed the AHP (Analytic Hierarchy Process) technique in 1971, 
about 25 years prior. AHP is a decision-making methodology which catches the appraisee's knowledge, experience and intuition through pairwise comparisons of the elements constituting the decision-making hierarchy structure [12]. AHP has been widely used in various decision-making areas due to of the simplicity and clarity of the theory as well as the convenience and universality of the application. And yet, since AHP is shown with a hierarchical structure, alternatives and decision criteria are regarded as independent. Thus, there exists a major demerit in that it cannot consider the comparison target's interdependence and is unable to provide feedback. ANP was developed to supplement this demerit presented an analysis method which considers interdependence and allows for feedback, thus applying a network structure. ANP is based on AHP and is a method which expands AHP up to a network structure which includes the interdependence and feedback of goals, standards, and alternatives. Thus, a more complicated structure can be constructed between clusters and between elements as compared to AHP. As a result, it has the merit of making more complicated decision-making possible, but to judge interdependence in this complicated structure, pairwise comparison of relatively more surveys is needed. Accordingly, considerable time and complex calculation are both required intandem $[12,13]$

ANP introduced the concept of a Super Matrix to apply interdependence and feedback to the process of decision-making. Through the Super Matrix, a weighted Super Matrix, and the involution of the Super Matrix, interdependence is converged to a certain value so as to calculate the weighted value implying dependencies, and this helps apply ANP to an environment generalized greater than AHP [14].

The first order of the ANP technique is the formation of the problem cluster and the construction of a network model through networking. The user constructs the goal of the present decision-making problem in the form of a network structure with several elements (nodes) corresponding to a number of several clusters. At this time, the correlation between the cluster and the element can be expressed using an arrow. The correlation is analyzed with experts' opinions and surveys. Figure 1 below is a general example of the network structure constructed like this.

Figure 1. The general network structure of ANP
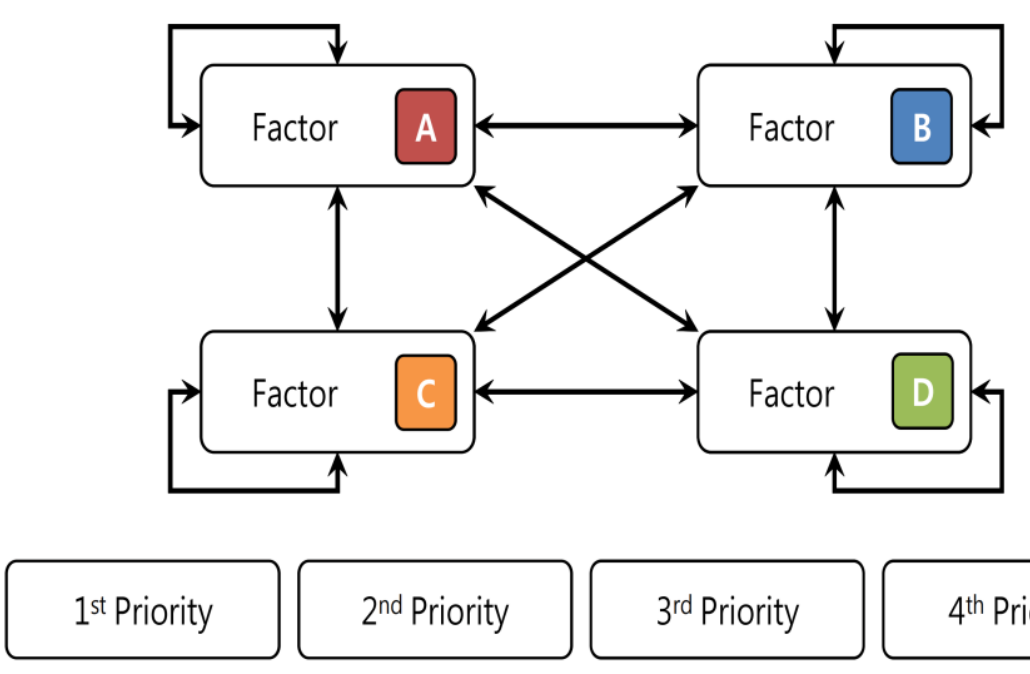

$4^{\text {th }}$ Priority

Pairwise comparisons are made between clusters and between elements in the cluster after a network structure is established. The pairwise comparison expresses the value of $a_{i j}$, the relative importance of element $i$ to element $j$ in a value between 1 and 9 points. In the pairwise comparison, the meaning of the importance is as seen in Table 2 below. 
Table 2. Fundamental Scales

\begin{tabular}{cc}
\hline Importance & Meaning \\
\hline 1 & Equal Importance \\
3 & Moderate Importance \\
5 & Essential or Strong Importance \\
7 & Demonstrated Importance \\
9 & Extreme Importance \\
$2,4,6,8$ & Reciprocals for Inverse Comparisons \\
\hline
\end{tabular}

A pairwise comparison matrix between clusters and elements is constructed based on a survey or investigation of relative importance. If $a_{i j}$ is the value of the matrix, the importance of the elements constituting the matrix can be calculated using Formula (1).

$$
A_{\omega}=\lambda_{\max } \omega
$$

In the above formula, $\lambda_{\max }$ is the maximum eigenvalue of $A$, and $\omega$ is the importance of the element, which is calculated by Formula (2) through standardization.

$$
\omega_{i}=\left[\sum_{j=1}^{n}\left(a_{i j} / \sum_{i=1}^{n} a_{i j}\right)\right] / n
$$

Through pairwise comparison, the weighted value is found between elements and alternatives, and is judged if the result of the pairwise comparison exhibits the consistency of being applied to the model by measuring the Consistency Ratio (CR). The CR is defined in Formula (4), which is the value dividing the Consistency Index (CI) by the Random Index (RI). CI judges consistency according to the proximity of $\lambda_{\max }$ to $n$, which is defined by Formula (3).

$$
\begin{aligned}
C I & =\frac{\left(\lambda_{\max }-n\right)}{(n-1)} \\
C R & =\frac{C I}{R I}
\end{aligned}
$$

Random Index is as seen in Table 3[15].

Table 3. Random Index

\begin{tabular}{ccccccccccc}
\hline Order & 1 & 2 & 3 & 4 & 5 & 6 & 7 & 8 & 9 & 10 \\
\hline R. I. & 0 & 0 & 0.52 & 0.89 & 1.11 & 1.25 & 1.35 & 1.40 & 1.45 & 1.49 \\
\hline
\end{tabular}

Saaty judged that a CR of less than 0.1 had rational consistency. Generally, to increase the reliability of the study, a consistency ratio of less than 0.1 is aimed for. Once the consistency verification is completed for the pairwise comparison, the importance of each element drawn through the pairwise comparison is constructed by means of a column vector to construct an early Super Matrix. Within the early Super Matrix, the row shows the element affected and the column shows the element affecting. If there is no influencing relationship, 0 appears at the junction, and if there is such a case, the degree of the impact appears at the junction. The early Super Matrix is shown as in Formula (5) in the form of matrix $W$. 


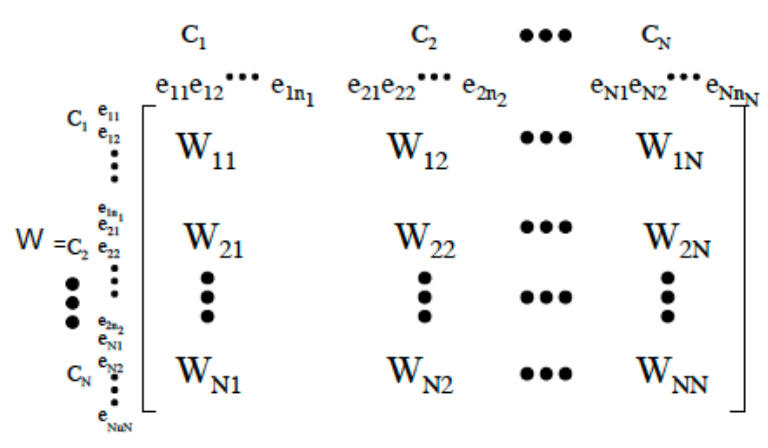

Once the early Super Matrix is constructed, the relevant element of each column of the early Super Matrix is multiplied by the weighted value between the clusters calculated previously so as to calculate the weighted Super Matrix. Once the weighted Super Matrix is drawn, it is necessary to calculate the extreme Super Matrix in order to know the degree of the impact of each element found in the network structure. ANP is a technique applying the concept of extreme probability in the Markov chain process, which calculates the weighted value by the involution of the weighted Super Matrix to converge to a fixed value, which is called extreme Super Matrix. This is expressed as Formula (6).

$$
\lim _{k \rightarrow \infty} W^{k}
$$

In the extreme Super Matrix, all the row values are converged to the same value in each row, and thus, the value of each row is the importance of the element.

\section{Analysis result}

\subsection{Drawing variables for decision-making}

To determine policies for revitalizing the DNA industry within the 4 th Industrial Revolution environment, this study conducted a primary in-depth interview with experts who investigate the domestic DNA industry in depth (1 from the Korea Information Society Development Institute, 1 from the Electronics and Telecommunications Research Institute, 1 from the National Information Society Agency (NIA), 1 from the Software Policy \& Research Institute, and 1 from the Korea Information \& Communication Industry Institute (KICI)), and conducted a secondary survey to draw priority based on the collected result from that. The secondary survey was conducted over a period of 30 days from June 15th through July 15th, 2020, and responses were collected from 15 experts at the Korea Information Society Development Institute, the Electronics and Telecommunications Research Institute, the Software Policy \& Research Institute, and the Korea Information \& Communication Industry Institute (KICI), as well as the National Information Society Agency (NIA), which promoted the development of the DNA industry as filling an important role. Then, ISM analysis was conducted through R software, and for ANP model analysis, the final priority was drawn, utilizing SUPER DECISIONS 2.08 software.

This study seeks to identify appropriate measures for securing competitiveness for the DNA industry, the core technology base of the digital economy under the 4th Industrial Revolution environment in order to support smooth convergence environment of other industries and generate higher added value competitiveness. For this purpose, this 
study comprehensively analyzed in-depth interviews and surveys with experts, and literature reviews related to the DNA industry while drawing key variables for the revitalization and empowerment of the DNA industry, as seen in Table 2 below.

As a result of the analysis, to revitalize the DNA industry, it was found that comprehensive policy measures would be necessary, centering around technology and infrastructure enhancement, market expansion and growth support, manpower training, and the establishment of a legal system. First, policy measures for technology and infrastructure enhancement include the enhancement of 5G mobile communication networks and security of nationwide coverage [16], the construction of big data centers and a platform for supporting data processing in public and private sectors [17], security of AI technological capability of a certain industry showing competitive advantage, and the establishment of a standardized system for DNA technology [18].

Table 4. Policy goals and detailed issues for the revitalization of the DNA industry

\begin{tabular}{|c|c|}
\hline Cluster & Node \\
\hline \multirow[t]{4}{*}{$\begin{array}{l}\text { Technology } \\
\text { and infra- } \\
\text { structure } \\
\text { enhance- } \\
\text { ment }\end{array}$} & A1. 5G network enhancement \\
\hline & $\begin{array}{l}\text { A2. Big data center and plat- } \\
\text { form construction }\end{array}$ \\
\hline & $\begin{array}{l}\text { A3. AI technology enhance- } \\
\text { ment }\end{array}$ \\
\hline & $\begin{array}{l}\text { A4. The establishment of a } \\
\text { standardized system for } \\
\text { DNA technology }\end{array}$ \\
\hline $\begin{array}{l}\text { Market ex- } \\
\text { pansion } \\
\text { and growth } \\
\text { support }\end{array}$ & $\begin{array}{l}\text { B1. The excavation and devel- } \\
\text { opment of large flagship busi- } \\
\text { ness }\end{array}$ \\
\hline
\end{tabular}

B2. The construction of $S / W$ convergence cluster by region

B3. The expansion of industrial demand

Enhancing 5G mobile communication network with hyper-connectivity and ultra-low latency as technical characteristics to operate various smart devices securely and seamlessly and securing nationwide coverage

Constructing big data center and platform to extract value from data in public and private sectors (digital dam)

Securing AI technological capability for certain strategic areas. Developing and enhancing innovation technology through the convergence of AI with other areas (new drugs, future materials, and medicine, etc.)

Establishing an international standard system of DNA technology such as IT, AI, and IoT, etc.

Excavating the government's large projects for the revitalization of the DNA industry and supporting flagship businesses

Constructing $\mathrm{S} / \mathrm{W}$ convergence center and innovating Free Economic Zone centering around new industries so that local convergence industries can enjoy global competitiveness

Supporting the creation of a new market, leveraging related companies' growth and start-ups' entry utilizing data and AI such as autonomous vehicles, AI robots, and bio/new medicine, etc.

B4. Global advancement supRevitalizing and supporting overseas port expansion of the DNA convergence 
industry with global competitiveness. ie. as K-medical care, K-Smart City, and K-culture

\begin{tabular}{cl}
\hline Manpower & $\mathrm{C} 1$. The establishment of a \\
training & $\begin{array}{l}\text { plan for the supply and de- } \\
\text { mand of national strategic } \\
\text { manpower }\end{array}$
\end{tabular}

C2. AI-SW Manpower Training

C3. Job retraining

D2. The innovation of data utilization

C4. The strengthening of AISW education and teacher competency in elementary, middle, and high school

$\begin{array}{cl}\text { Establish- } & \text { D1. Primary legislation rear- } \\ \text { ment of the } & \begin{array}{l}\text { rangement and follow-up } \\ \text { legal sys- } \\ \text { measures }\end{array}\end{array}$

D3. The prevention of ad-
verse effects and the creation
of an environment of use
Preparing a comprehensive and systematic plan for the supply and demand of strategic manpower for the demand and supply of employment in the DNA industry at the state level

Short-term support of the industry through the designation of AI-SW convergence university and AI convergence graduate school and policy support

Supporting the customized AI job retaining as required by the industry and constructing a lifelong education system

Systematic strengthening of AI-SW education and teacher competency at elementary, middle, and high school levels

Enacting intelligent information fundamental law and three data bills. Maintaining follow-up measures and enforcement ordinance. Legislating laws for revitalization under the $\mathrm{AI}$ and Blockchain Promotion Act, etc.

Opening administration and public institutions' data. Inducing utilization. Designating and spreading my data businesses

Rearranging the environment of the use, like preparing AI ethical policies and preventing smart information gap

Second, policy measures for market expansion and growth support include the excavation and supporting of major projects and flagship businesses, SW convergence cluster construction by region [19], the expansion of industrial demand including the promotion of start-ups utilizing data/AI, etc. [20], and the revitalization of overseas expansion of the DNA industry with global competitiveness [21].

Third, for manpower training, it turned out that it would be necessary to prepare a plan for the supply and demand of strategic manpower within the DNA industry [22], train quality human resources for AI-SW as needed in the industry, support of AI job retraining, construction of a lifelong education system and strengthening of AI-SW education and teacher competency at the elementary, middle, and high schools levels.

Lastly, for the establishment of a legal system, follow-up measures and the maintenance of the enforcement ordinance are necessary following the primary legislation, and the utilization of public and private data, the ethical policies of the DNA industry, and the resolution of the digital divide would also be needed. 


\subsubsection{Structural Self-Interaction Matrix (SSIM)}

SSIM was discussed with experts so as to determine the rational priorities for the revitalization of the DNA industry, as in Table 5. Through experts' meetings, conceptual correlations among the attribute factors were investigated. As seen in Table 5, they were marked, using V, A, X, and O in constructing SSIM. The 15 evaluation attributed factors were compared.

Table 5. Structural Self-Interaction Matrix (SSIM)

\begin{tabular}{ccccccccccccccc}
\hline & D3 & D2 & D1 & C4 & C3 & C2 & C1 & B4 & B3 & B2 & B1 & A4 & A3 & A2 \\
\hline A1 & O & V & V & O & O & V & A & O & O & O & O & O & O & O \\
A2 & O & V & V & O & O & O & A & O & O & O & O & O & O & \\
A3 & V & V & V & O & O & V & A & O & O & O & O & O & & \\
A4 & V & V & V & O & O & V & A & O & O & O & O & & & \\
B1 & V & V & V & O & O & V & A & O & O & O & & & & \\
B2 & A & A & A & O & O & A & O & X & V & & & & & \\
B3 & A & A & A & O & O & A & O & A & & & & & & \\
B4 & A & A & A & O & O & A & O & & & & & & & \\
C1 & O & O & O & O & O & V & & & & & & & & \\
C2 & O & O & O & A & A & & & & & & & & & \\
C3 & O & O & O & O & & & & & & & & & & \\
C4 & O & O & O & & & & & & & & & & & \\
D1 & O & O & & & & & & & & & & & & \\
D2 & O & & & & & & & & & & & & & \\
\hline
\end{tabular}

\subsubsection{Reachability}

Symbols, V, A, X, and O used in Table 5 are displayed after being changed into 1 or 0 . Through this, using SSIM drawn in Table 5, Initial Reachability Matrix was created as seen in Table 6 below.

Table 6. Initial reachability matrix

\begin{tabular}{cccccccccccccccc}
\hline & A1 & A2 & A3 & A4 & B1 & B2 & B3 & B4 & C1 & C2 & C3 & C4 & D1 & D2 & D3 \\
\hline A1 & 1 & 0 & 0 & 0 & 0 & 0 & 0 & 0 & 0 & 1 & 0 & 0 & 1 & 1 & 0 \\
A2 & 0 & 1 & 0 & 0 & 0 & 0 & 0 & 0 & 0 & 0 & 0 & 0 & 1 & 1 & 0 \\
A3 & 0 & 0 & 1 & 0 & 0 & 0 & 0 & 0 & 0 & 1 & 0 & 0 & 1 & 1 & 1 \\
A4 & 0 & 0 & 0 & 1 & 0 & 0 & 0 & 0 & 0 & 1 & 0 & 0 & 1 & 1 & 1 \\
B1 & 0 & 0 & 0 & 0 & 1 & 0 & 0 & 0 & 0 & 1 & 0 & 0 & 1 & 1 & 1 \\
B2 & 0 & 0 & 0 & 0 & 0 & 1 & 1 & 1 & 0 & 0 & 0 & 0 & 0 & 0 & 0 \\
B3 & 0 & 0 & 0 & 0 & 0 & 0 & 1 & 0 & 0 & 0 & 0 & 0 & 0 & 0 & 0 \\
B4 & 0 & 0 & 0 & 0 & 0 & 1 & 1 & 1 & 0 & 0 & 0 & 0 & 0 & 0 & 0 \\
C1 & 1 & 1 & 1 & 1 & 1 & 0 & 0 & 0 & 1 & 1 & 0 & 0 & 0 & 0 & 0 \\
C2 & 0 & 0 & 0 & 0 & 0 & 1 & 1 & 1 & 0 & 1 & 0 & 0 & 0 & 0 & 0 \\
C3 & 0 & 0 & 0 & 0 & 0 & 0 & 0 & 0 & 0 & 1 & 1 & 0 & 0 & 0 & 0 \\
C4 & 0 & 0 & 0 & 0 & 0 & 0 & 0 & 0 & 0 & 1 & 0 & 1 & 0 & 0 & 0 \\
D1 & 0 & 0 & 0 & 0 & 0 & 1 & 1 & 1 & 0 & 0 & 0 & 0 & 1 & 0 & 0
\end{tabular}




\begin{tabular}{llllllllllllllll} 
D2 & 0 & 0 & 0 & 0 & 0 & 1 & 1 & 1 & 0 & 0 & 0 & 0 & 0 & 1 & 0 \\
D3 & 0 & 0 & 0 & 0 & 0 & 1 & 1 & 1 & 0 & 0 & 0 & 0 & 0 & 0 & 1 \\
\hline
\end{tabular}

To test the consistency of the preference system of each factor, the reason described in Session 2, transitivity was checked to create the final reachability matrix.

Table 7. Final reachability matrix

\begin{tabular}{ccccccccccccccccc}
\hline & A1 & A2 & A3 & A4 & B1 & B2 & B3 & B4 & C1 & C2 & C3 & C4 & D1 & D2 & D3 & Dr. \\
\hline A1 & 1 & 0 & 0 & 0 & 0 & $1^{*}$ & $1^{*}$ & $1^{*}$ & 0 & 1 & 0 & 0 & 1 & 1 & 0 & 7 \\
A2 & 0 & 1 & 0 & 0 & 0 & $1^{*}$ & $1^{*}$ & $1^{*}$ & 0 & 0 & 0 & 0 & 1 & 1 & 0 & 6 \\
A3 & 0 & 0 & 1 & 0 & 0 & $1^{*}$ & $1^{*}$ & $1^{*}$ & 0 & 1 & 0 & 0 & 1 & 1 & 1 & 8 \\
A4 & 0 & 0 & 0 & 1 & 0 & $1^{*}$ & $1^{*}$ & $1^{*}$ & 0 & 1 & 0 & 0 & 1 & 1 & 1 & 8 \\
B1 & 0 & 0 & 0 & 0 & 1 & $1^{*}$ & $1^{*}$ & $1^{*}$ & 0 & 1 & 0 & 0 & 1 & 1 & 1 & 8 \\
B2 & 0 & 0 & 0 & 0 & 0 & 1 & 1 & 1 & 0 & 0 & 0 & 0 & 0 & 0 & 0 & 3 \\
B3 & 0 & 0 & 0 & 0 & 0 & 0 & 1 & 0 & 0 & 0 & 0 & 0 & 0 & 0 & 0 & 1 \\
B4 & 0 & 0 & 0 & 0 & 0 & 1 & 1 & 1 & 0 & 0 & 0 & 0 & 0 & 0 & 0 & 3 \\
C1 & 1 & 1 & 1 & 1 & 1 & $1^{*}$ & $1^{*}$ & $1^{*}$ & 1 & 1 & 0 & 0 & $1^{*}$ & $1^{*}$ & $1^{*}$ & 13 \\
C2 & 0 & 0 & 0 & 0 & 0 & 1 & 1 & 1 & 0 & 1 & 0 & 0 & 0 & 0 & 0 & 4 \\
C3 & 0 & 0 & 0 & 0 & 0 & $1^{*}$ & $1^{*}$ & $1^{*}$ & 0 & 1 & 1 & 0 & 0 & 0 & 0 & 5 \\
C4 & 0 & 0 & 0 & 0 & 0 & $1^{*}$ & $1^{*}$ & $1^{*}$ & 0 & 1 & 0 & 1 & 0 & 0 & 0 & 5 \\
D1 & 0 & 0 & 0 & 0 & 0 & 1 & 1 & 1 & 0 & 0 & 0 & 0 & 1 & 0 & 0 & 4 \\
D2 & 0 & 0 & 0 & 0 & 0 & 1 & 1 & 1 & 0 & 0 & 0 & 0 & 0 & 1 & 0 & 4 \\
D3 & 0 & 0 & 0 & 0 & 0 & 1 & 1 & 1 & 0 & 0 & 0 & 0 & 0 & 0 & 1 & 4 \\
De. & 2 & 2 & 2 & 2 & 2 & 14 & 15 & 14 & 1 & 8 & 1 & 1 & 7 & 7 & 5 & $83 / 83$ \\
\hline \multicolumn{1}{c}{ and 1 signifies the values in table 7 appearing due to the transitive relationship } \\
\end{tabular}

In Table 7, the value of Driving Power refers to the total number of times the impact of each factor was imposed on other factors, including itself. In addition, Dependence Power refers to the total number of times the impact of other factors was born on the factor [6]. Thus, the more Driving Power, the greater the influence of the factor on other factors becomes while the more Dependence Power, the more the impact of other factors on the factor becomes.

\subsubsection{Stratification of Reachability Matrix}

Then, based on the Reachability Matrix as calculated for the structuralization of factors, the Intersection is found as the common element between Reachability Set and Antecedent Set.

The value of Intersection is affected by reachability, and the reachability value not affecting other elements is located at the top level. This is summarized in Table 8.

Table 8. Final results of the iteration

\begin{tabular}{cccc}
\hline Reachability Set & Antecedents Set & Intersection Set & Level \\
\hline & A1 A2 A3 A4 B1 B2 B3 & & \\
B3 & B4 C1 C2 C3 C4 D1 D2 & B3 & 1
\end{tabular}


B2 B4

B2 B4

C2

D1

D2

D3

A1

A2

A3

A4

B1

C3

C4

C1
A1 A2 A3 A4 B1 B2 B4

C1 C2 C3 C4 D1 D2 D3

A1 A2 A3 A4 B1 B2 B4

C1 C2 C3 C4 D1 D2 D3

A1 A3 A4 B1 C1 C2 C3

C4

A1 A2 A3 A4 B1 C1 D1

A1 A2 A3 A4 B1 C1 D2

A3 A4 B1 C1 D3

A1 C1

A2 C1

A3 C1

A4 C1

B1 C1

C3

C4

C1
B2 B4

2

B2 B4

2

C2

3

D1

3

D2

3

D3

3

A1

4

A2

4

A3

4

A4

4

B1

4

C3

4

C4

4

5

\subsubsection{Results of the ISM Directional Graph and Model}

The final result of the ISM analysis method is shown in Figure 3. To sum up, the most important thing aimed at in this plan is the expansion of industrial demand (B3). To fulfill this core purpose, strategies for the construction of an SW convergence cluster by region and support for global advancement are prioritized. It is necessary to construct an SW convergence cluster by region (B2), construct a supply base for DNA-related services and 
goods, expand the market through global advancement support (B4) and expand the economies of scale along with scope.

To compose these two factors, they should be achieved, including 5G network enhancement (A1), Big data center and platform construction (A2), AI technology enhancement (A3), and the establishment of a standardized system for DNA technology (A4). To achieve these factors, fundamentally, a manpower supply as well as a demand system should be constructed as a state-level strategy, in conclusion (C1).

This may be taken for granted in some sense. To maximize industrial demands for DNA, fundamentally, the potential of human resources is the element which must be achieved first. And yet, what requires attention in the interpretation of ISM is that C1 is the element which must be achieved first rather than the most important one, and the priority in AHP/ANPD is the element towards which the most resources must be devoted.

To sum up again, through the expansion of human resources, it is necessary to engage in strategies to expand the potential of DNA and to expand supply for spreading demand.

Figure 2. The interpretive structural modeling (ISM) model of DNA Policies

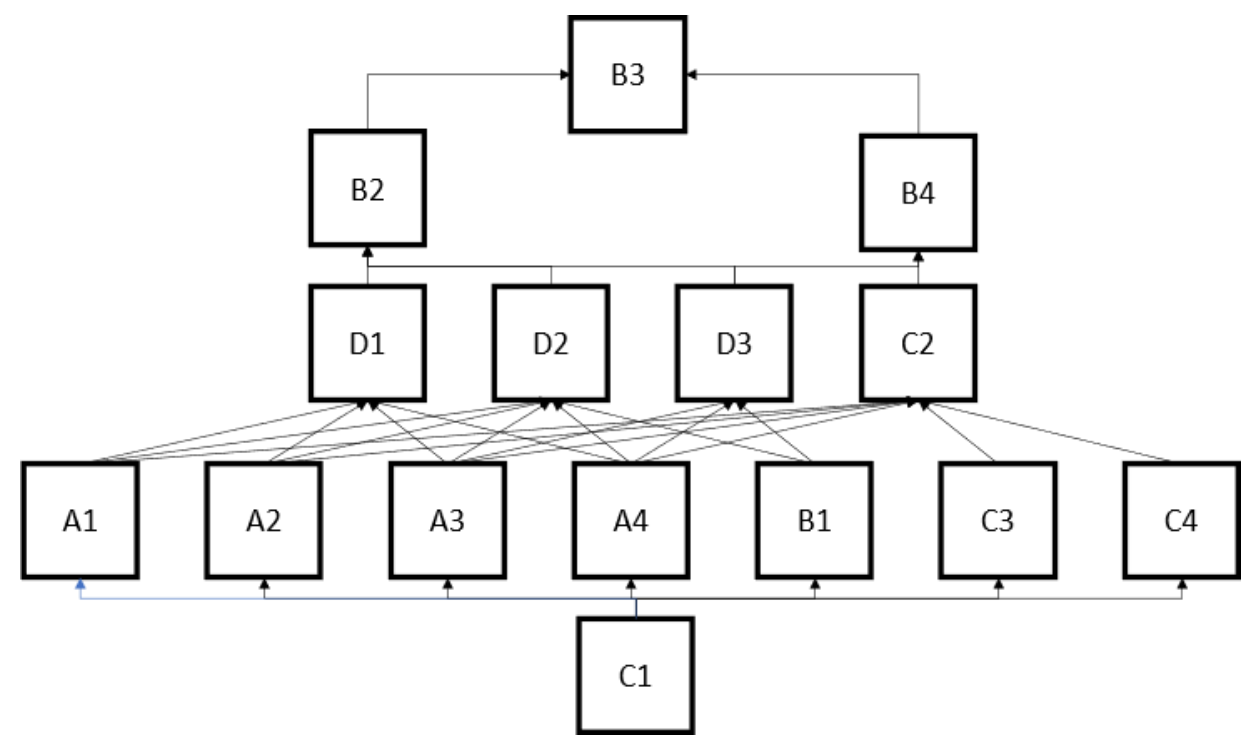

\subsection{Result of ANP analysis}

To discover the priorities of policies for the revitalization of the DNA industry, policy goals (clusters) were set up, and policy elements (nodes) were drawn by subdividing them per policy goal. The correlations between policy elements were analyzed, considering interdependence and feedback, etc.

As a result of the analysis, the correlations between policies for the revitalization of the DNA industry were drawn as shown in Table 9 . Table 9 below can be interpreted as follows $5 \mathrm{G}$ network enhancement (A1) policies had close correlations with big data center and platform construction, AI technology enhancement, the establishment of a standardized system for DNA technology, large flagship business excavation and development, industrial demand expansion, data utilization innovation, the prevention of adverse effect, and the creation of an environment of use.

Table 9. Analysis of the correlation between subdivided policy elements

\begin{tabular}{|c|c|c|c|c|c|c|c|c|c|c|c|c|c|c|c|}
\hline \multirow[b]{2}{*}{$\begin{array}{l}\text { Classifi- } \\
\text { cation }\end{array}$} & \multicolumn{4}{|c|}{ A } & \multicolumn{4}{|c|}{ B } & \multicolumn{4}{|c|}{ C } & \multicolumn{3}{|c|}{ D } \\
\hline & $\begin{array}{c}\mathrm{a} . \\
1\end{array}$ & & a.3 & a. 4 & $\begin{array}{l}b . \\
1\end{array}$ & $\begin{array}{l}b . \\
2\end{array}$ & $\begin{array}{l}b . \\
3\end{array}$ & $\begin{array}{l}b . \\
4\end{array}$ & $\begin{array}{l}\text { c. } \\
1\end{array}$ & $\begin{array}{l}\text { c. } \\
2\end{array}$ & $\begin{array}{l}\text { c. } \\
3\end{array}$ & $\begin{array}{l}\text { c. } \\
4\end{array}$ & $\begin{array}{l}\mathrm{d} . \\
1\end{array}$ & $\begin{array}{l}\mathrm{d} . \\
2\end{array}$ & $\begin{array}{c}\text { d. } \\
3\end{array}$ \\
\hline
\end{tabular}




\begin{tabular}{|c|c|c|c|c|c|c|c|c|c|c|c|c|c|c|c|c|}
\hline & a.1 & & $\sqrt{ }$ & $\sqrt{ }$ & $\sqrt{ }$ & $\sqrt{ }$ & & $\sqrt{ }$ & $\sqrt{ }$ & & & & & & & \\
\hline \multirow{4}{*}{ A } & a. 2 & $\sqrt{ }$ & & $\sqrt{ }$ & $\sqrt{ }$ & $\sqrt{ }$ & $\sqrt{ }$ & $\sqrt{ }$ & $\sqrt{ }$ & $\sqrt{ }$ & $\sqrt{ }$ & & & $\sqrt{ }$ & $\sqrt{ }$ & \\
\hline & a.3 & $\sqrt{ }$ & $\sqrt{ }$ & & $\sqrt{ }$ & & $\sqrt{ }$ & $\sqrt{ }$ & & $\sqrt{ }$ & $\sqrt{ }$ & & & $\sqrt{ }$ & $\sqrt{ }$ & \\
\hline & a.4 & $\sqrt{ }$ & $\sqrt{ }$ & $\sqrt{ }$ & & & & $\sqrt{ }$ & $\sqrt{ }$ & & $\sqrt{ }$ & & & $\sqrt{ }$ & $\sqrt{ }$ & \\
\hline & b.1 & $\sqrt{ }$ & $\sqrt{ }$ & $\sqrt{ }$ & $\sqrt{ }$ & & $\sqrt{ }$ & $\sqrt{ }$ & & & & & & $\sqrt{ }$ & $\sqrt{ }$ & \\
\hline \multirow{4}{*}{ B } & b. 2 & & $\sqrt{ }$ & $\sqrt{ }$ & $\sqrt{ }$ & $\sqrt{ }$ & & $\sqrt{ }$ & $\sqrt{ }$ & & $\sqrt{ }$ & $\sqrt{ }$ & & $\sqrt{ }$ & & \\
\hline & b.3 & $\sqrt{ }$ & $\sqrt{ }$ & $\sqrt{ }$ & $\sqrt{ }$ & $\sqrt{ }$ & $\sqrt{ }$ & & $\sqrt{ }$ & $\sqrt{ }$ & $\sqrt{ }$ & $\sqrt{ }$ & $\sqrt{ }$ & $\sqrt{ }$ & $\sqrt{ }$ & $\sqrt{ }$ \\
\hline & b.4 & & $\sqrt{ }$ & & $\sqrt{ }$ & & $\sqrt{ }$ & $\sqrt{ }$ & & $\sqrt{ }$ & $\sqrt{ }$ & & & $\sqrt{ }$ & $\sqrt{ }$ & \\
\hline & c. 1 & & & $\sqrt{ }$ & & $\sqrt{ }$ & & $\sqrt{ }$ & & & $\sqrt{ }$ & $\sqrt{ }$ & $\sqrt{ }$ & & & $\sqrt{ }$ \\
\hline \multirow{4}{*}{ C } & c. 2 & & $\sqrt{ }$ & $\sqrt{ }$ & & $\sqrt{ }$ & $\sqrt{ }$ & $\sqrt{ }$ & & $\sqrt{ }$ & & $\sqrt{ }$ & $\sqrt{ }$ & $\sqrt{ }$ & $\sqrt{ }$ & $\sqrt{ }$ \\
\hline & c.3 & & & & & $\sqrt{ }$ & $\sqrt{ }$ & $\sqrt{ }$ & & $\sqrt{ }$ & $\sqrt{ }$ & & & & & \\
\hline & c. 4 & & & & & & & $\sqrt{ }$ & & $\sqrt{ }$ & $\sqrt{ }$ & & & $\sqrt{ }$ & & $\sqrt{ }$ \\
\hline & d.1 & & & $\sqrt{ }$ & & & $\sqrt{ }$ & & $\sqrt{ }$ & $\sqrt{ }$ & & & & & $\sqrt{ }$ & $\sqrt{ }$ \\
\hline \multirow[t]{2}{*}{ D } & d.2 & $\sqrt{ }$ & $\sqrt{ }$ & $\sqrt{ }$ & $\sqrt{ }$ & $\sqrt{ }$ & & $\sqrt{ }$ & & & $\sqrt{ }$ & & & $\sqrt{ }$ & & \\
\hline & d.3 & $\sqrt{ }$ & & $\sqrt{ }$ & & & & $\sqrt{ }$ & & & & $\sqrt{ }$ & $\sqrt{ }$ & $\sqrt{ }$ & $\sqrt{ }$ & \\
\hline
\end{tabular}

The results of the analysis of the priorities of the variables of policies for the revitalization of the DNA industry are as seen in Table 4. The ANP model is a method for setting priorities, considering the correlations among a range of different variables in terms of related policy-making and decision-making, which is an effective methodology for establishing policy measures. As a result of the analysis, the order of policy goals (clusters) for the revitalization of the DNA industry was as follows: market expansion and growth support $(33.4 \%) \rightarrow$ technology and infrastructure enhancement $(23.9 \%) \rightarrow$ establishment of legal system $(22.2 \%) \rightarrow$ manpower training $(20.4 \%)$.

Table 10. Analysis of the correlations among the subdivided policy elements

\begin{tabular}{ccccc}
\hline Classification & $\begin{array}{c}\text { A. Technology } \\
\text { and infrastruc- } \\
\text { ture enhance- } \\
\text { ment }\end{array}$ & $\begin{array}{c}\text { B. Market ex- } \\
\text { pansion and } \\
\text { growth sup- } \\
\text { port }\end{array}$ & $\begin{array}{c}\text { C. Manpower } \\
\text { training }\end{array}$ & $\begin{array}{c}\text { D. Establish- } \\
\text { ment of legal } \\
\text { system }\end{array}$ \\
\hline $\begin{array}{c}\text { Weighted } \\
\text { value }\end{array}$ & 0.23914 & 0.334151 & 0.204645 & 0.222065 \\
\hline
\end{tabular}

The ranking of the policy elements (nodes) included in these policy goals (clusters) can be examined as follows. First, for the growth of the DNA industry, the policy goal of "market spread and growth support" was found to be most important. This can more clearly be known in terms of the priorities of the subdivided policy elements for the revitalization of the DNA industry. The ranking of policy elements in the area of market expansion and growth support (33.4\%) was in the following order of importance: industrial demand expansion $(10.0 \%, 1 \mathrm{st}) \rightarrow \mathrm{SW}$ convergence cluster construction $(9.3 \%$, 2nd $) \rightarrow$ Global advancement support $(8.0 \%, 3 \mathrm{rd}) \rightarrow$ Large flagship business excavation and development $(6.0 \%, 10$ th). The experts judged that the area of market spread and growth support took the 1st, 2nd, and 3rd positions of all policy elements for the revitalization of the DNA industry. This result indicates that generating market demand in the DNA industry earlier is the key condition of industry revitalization. In other words, actively promoting policies for excavating and supporting innovation enterprises which utilize data/AI, such as autonomous vehicles, AI robots, and bio/new medicine, etc. And startup businesses based on DNA technology, constructing SW convergence cluster by region and preparing a novel growth engine by Free Economic Zone innovation centered around new industries, and supporting the overseas expansion of the convergence industries such 
as K-medical care, K-Smart City, and K-culture with their global competitiveness recognized after COVID-19 are the most important policy elements of all. In contrast, how the government directly selects leading businesses and promotes business was ranked low, and this result provides an implication that for the leading business of the DNA industry, differentiation for the promotion of the business based on cooperation with the private sector is effective rather than being led by government.

Second, "technology and infrastructure enhancement $(23.9 \%)$ " is the creation of the technological base for the DNA industry, which was ranked 2nd in the priorities of policy goals. The ranking of policy elements in the area of technology and infrastructure enhancement was in the following order of importance: Big data center and platform construction $(6.5 \%, 8$ th $) \rightarrow 5 \mathrm{G}$ network enhancement $(6.3 \%, 9$ th $) \rightarrow$ AI technology enhancement $(5.9 \%, 11$ th $) \rightarrow$ Establishment of a standardized system for DNA technology $(5.0 \%$, 12th). This result makes clear that since technology and infrastructure rapidly evolve throughout the 4th Industrial Revolution environment, it is very important to secure core technologies such as data, network, and AI. In particular, as compared to the policy for securing the competitiveness of individual technology within the DNA industry, the policy for systematically promoting standardization of DNA technologies was ranked relatively low.

Third, the "establishment of the legal system (22.2\%)" is the creation of the institutional base in the new area of the DNA industry, which was ranked 3rd in terms of the priorities of policy goals. Of note, what requires attention in the area of the establishment of the legal system is that the importance of policy goals were ranked 3rd; however, the subdivided policy elements were ranked quite high. The result of the analysis of priorities of policy elements in the area of the establishment of the legal system was as follows: Data utilization innovation $(7.7 \%, 5$ th $) \rightarrow$ primary legislation rearrangement and follow-up measures $(7.2 \%, 6$ th $) \rightarrow$ The prevention of adverse effects and the creation of an environment of use $(7.2 \%, 7 \mathrm{th})$. As known in the numerical values, of all policy elements for the revitalization of the DNA industry, policy elements in the area of the legal system took the 4 th, 5 th, and 6 th positions. This result indicates that in terms of fostering new industries such as the DNA industry, it is very important to prepare a legal systematic framework preemptively. Accordingly, following the amendment of the Three Data Bills, it is urgently necessary to improve the maintenance of subordinate laws so that data may be utilized substantively, as well as to promote the maintenance of subordinate laws for the execution of an intelligent information fundamental law, the primary legislation in the 4th Industrial Revolution. Besides, it is necessary to improve the system for the prevention of adverse effects such as the digital divide and creating a safe environment with respect to education as to how to use smart devices.

Fourth, "manpower training $(20.4 \%)$ " is the securing of the outstanding workforce as required by the DNA industry, which was ranked the lowest with respect to the priorities of policy goals. The ranking of policy elements in the area of manpower training was as follows: AI-SW manpower training $(7.9 \%, 4$ th $) \rightarrow$ The establishment of a plan for supply and demand for national strategic manpower $(4.5 \%, 13$ th $) \rightarrow$ strengthening of AI-SW education and teacher competency in elementary, middle, and high schools $(4.1 \%, 14$ th $) \rightarrow$ Job retraining $(3.8 \%, 15$ th). Manpower training was ranked relatively low; however, its importance was $20.4 \%$, so there was not an overly major difference. In other words, the policy goal of manpower training too was at a similar level in terms of substantive importance to technology and infrastructure enhancement and the establishment of the legal system. In particular, the 'AI-SW manpower training (7.9\%)' policy of educating highquality professionals in the short term was so urgent that it was ranked 4 th out of all policy elements. And yet, the importance of the other policy elements of manpower training 
were ranked lower overall, and this was chiefly because, compared to the urgency of the revitalization of the DNA industry, manpower training is a policy which is time consuming.

Table 11. Comparison of analysis results by the priority of ANP model

\begin{tabular}{|c|c|c|c|}
\hline Cluster & Node & The priority of ex & \\
\hline \multirow{4}{*}{$\begin{array}{l}\text { A. Technology and } \\
\text { infrastructure } \\
\text { enhancement }\end{array}$} & a.1 5G network enhancement & 0.063801 & 9 \\
\hline & $\begin{array}{l}\text { a. } 2 \text { Big data center and plat- } \\
\text { form construction }\end{array}$ & 0.065333 & 8 \\
\hline & $\begin{array}{l}\text { a.3 AI technology enhance- } \\
\text { ment }\end{array}$ & 0.059582 & 11 \\
\hline & $\begin{array}{l}\text { a.4 The establishment of a } \\
\text { standardized system for DNA } \\
\text { technology }\end{array}$ & 0.050424 & 12 \\
\hline \multirow{4}{*}{$\begin{array}{l}\text { B. Market expan- } \\
\text { sion and growth } \\
\text { support }\end{array}$} & $\begin{array}{l}\text { b.1 Large flagship business ex- } \\
\text { cavation and promotion }\end{array}$ & 0.060077 & 10 \\
\hline & $\begin{array}{l}\text { b.2 SW convergence cluster } \\
\text { construction by region }\end{array}$ & 0.093400 & 2 \\
\hline & $\begin{array}{l}\text { b.3 The expansion of indus- } \\
\text { trial demand }\end{array}$ & 0.100451 & 1 \\
\hline & $\begin{array}{l}\text { b.4 Global advancement sup- } \\
\text { port }\end{array}$ & 0.080223 & 3 \\
\hline \multirow{5}{*}{$\begin{array}{l}\text { C. Manpower train- } \\
\text { ing }\end{array}$} & $\begin{array}{l}\text { c.1 Establishment of a plan for } \\
\text { supply and demand for na- } \\
\text { tional strategic manpower }\end{array}$ & 0.045198 & 13 \\
\hline & c.2 AI-SW Manpower & 0.079545 & 4 \\
\hline & Training & & \\
\hline & c.3 Job retraining & 0.038558 & 15 \\
\hline & $\begin{array}{l}\text { c. } 4 \text { Strengthening of AI-SW } \\
\text { education and teacher compe- } \\
\text { tency in elementary, middle, } \\
\text { and high school }\end{array}$ & 0.041344 & 14 \\
\hline \multirow{3}{*}{$\begin{array}{l}\text { D. establishment of } \\
\text { legal system }\end{array}$} & $\begin{array}{l}\text { d.1 Primary legislation rear- } \\
\text { rangement and follow-up } \\
\text { measures }\end{array}$ & 0.072829 & 6 \\
\hline & $\begin{array}{l}\text { d.2 Data utilization innova- } \\
\text { tion }\end{array}$ & 0.077156 & 5 \\
\hline & $\begin{array}{l}\text { d. } 3 \text { The prevention of adverse } \\
\text { effect and the creation of an } \\
\text { environment of use }\end{array}$ & 0.07208 & 7 \\
\hline
\end{tabular}

\section{Discussion and Conclusion}

Thus far, this study diagnosed the technological possibilities of data (D), network (N), and AI (A) leading the digital economy throughout the rapidly changing 4th Industrial Revolution environment, analyzed various policy measures for the revitalization of the DNA industry intensively, and drew priorities in terms of the policies through the ISMANP analysis model to develop the DNA industry effectively under limited budget 
restrictions. As a result of the analysis, in South Korea, the following policy implications would be important in terms of fostering the DNA industry effectively.

First, it turned out that the most important policy goal for the revitalization of the DNA industry was market expansion along with growth support. In other words, to foster the DNA industry, the methods implemented to create early market demand is important. This result shows that in the industries in which technological evolution is rapidly progressing such as in the DNA industry, policy support is needed, which can give rise to voluntary demand by market function. In ISM model analysis, the spread of industrial demand was determined to be the most important factor, and in the actual quantitative analysis by ANP model, the area of market expansion and growth support was the only one which showed a level of importance over $30 \%$.

Second, of the policy goals in the DNA industry, with the exception of market expansion and growth support, technology and infrastructure enhancement, the establishment of the legal system, and manpower training showed similar importance. This shows that all policy goals, including those pertaining to technology and infrastructure enhancement, the establishment of the legal system, and manpower training are important for the fostering of the DNA industry.

Third, within the analysis of the subdivided policy elements, short-term policies were more important than long-term ones. For example, in technology and infrastructure enhancement, the priority of the policy to enhance individual technology which was behind developed countries in the short term was high, and in manpower training, AI-SW manpower training for manpower shortage in the short term at colleges in the industrial world was ranked 4th. As for the priorities of policies within the DNA industry, it is necessary to concentrate on differentiated policies which can secure competitiveness in the short term such as the enhancement of source technologies which are behind developed countries.

This study has an important policy contribution with respect to the setting of the direction of government policies to convert to digital economy with the DNA industry such as driverless cars, smart factory, and post smartphone as the core foundation in the 4th Industrial Revolution environment and has a theoretical contribution as the first study which quantitatively approaches the priorities of policies for the revitalization of the DNA industry. In particular, South Korea's experience will also be an important lesson for other countries for fostering the DNA industry as a growth engine in a new intelligent information environment by policies.

Author Contributions: Jeong Ho Kwak, Yonghee Kim designed the experiments; Jeong Ho Kwak collected and analyzed ANP and Survey data; Yonghee Kim analyzed ISM data; Yonghee Kim and Jeong Ho Kwak wrote the manuscript.

Funding: This research received no external funding

Conflicts of Interest: The authors declare no conflict of interest.

\section{References}

1. Related Government Departments, Data Industry Revitalization Strategy. 2018: 4th Industrial Revolution Committee Resolution.

2. Related Government Departments, Data/AI Economy Revitalization Plan. 2019, Innovative Growth Strategy Meeting.

3. Ministry of Science and ICT, Hyper-Connected Intelligent Network Construction Strategy to Get Ready for the 4th Industrial Revolution. 2017, Ministry of Science and ICT.

4. Ministry of Science and ICT, 2018 Mobile Communication Frequency Allocation Plan Confirmation and Notification-related Briefing. 2018. 
5. Ministry of Science and ICT, Artificial Intelligence (AI) R\&D Strategy. 2018, 4th Industrial Revolution Committee.

6. Kim, Y., Y. Park, and G. Song, Interpretive Structural Modeling in the Adoption of IoT Services. KSII Transactions on Internet \& Information Systems, 2019. 13(3).

7. Kumar, D.T., et al., Analyzing the CSR issues behind the supplier selection process using ISM approach. Resources, Conservation and Recycling, 2014. 92: p. 268-278.

8. Singh, M. and R. Kant, Knowledge management barriers: An interpretive structural modeling approach. International Journal of Management Science and Engineering Management, 2008. 3(2): p. 141-150.

9. Wong, J.K.W. and J.K. Leung, modelling factors influencing the adoption of smart-home technologies. Facilities, 2016.

10. Anand, A. and G. Bansal, Interpretive structural modelling for attributes of software quality. Journal of Advances in Management Research, 2017.

11. Mandal, A. and S. Deshmukh, Vendor selection using interpretive structural modelling (ISM). International journal of operations \& production management, 1994.

12. Saaty, T.L., What is the analytic hierarchy process? in Mathematical models for decision support. 1988, Springer. p. 109-121.

13. Saaty, T.L., Highlights and critical points in the theory and application of the analytic hierarchy process. European journal of operational research, 1994. 74(3): p. 426-447.

14. Saaty, T.L., How to make a decision: the analytic hierarchy process. Interfaces, 1994. 24(6): p. 19-43.

15. Saaty, T.L. and L.G. Vargas, the analytic network process, in Decision making with the analytic network process. 2013, Springer. p. $1-40$.

16. IITP, The trend of Global DNA: Digital Healthcare, in ICT Brief. 2020.

17. En-Core. The Core of the Fourth Industrial Revolution: Data Economy. in Data Grand Conference. 2016. SEOUL.

18. Yang, H.T., et al., Artificial Intelligence Technology Prospect and Innovation Strategy Direction-State Artificial Intelligence R\&D Policy Improvement Plan. Policy Studies, 2019: p. 1-321.

19. Lim, Y. and M. Choi, Mid/long-term SW R\&D project candidates discovery and promotion system. 2018, SPRi.

20. Ministry of Science and ICT, Software Convergence Cluster 2.0 Creation. 2019.

21. Kim, S., J. Kang, and G. Son, A Study on Developing ICT Innovative Technology-based Startups. Study on the Policy of Broadcasting and Communication, 2018.12. 2018-0-00331.

22. Lee, S., et al., Mid- to long-term manpower demand forecast reflecting technological innovation. 2017, Korea Employment Information Service. 